\title{
ANALISIS PENGARUH KEBIJAKAN PEMERINTAH TERHADAP NILAI TUKAR RUPIAH SETELAH KRISIS EKONOMI GLOBAL 2008
}

\author{
Dwita Sakuntala \\ Juli Meliza \\ Fakultas Ekonomi Universitas Prima Indonesia \\ Email: dwitasakuntala@unprimdn.ac.id
}

\begin{abstract}
At the end of 2008 there was a financial crisis in America that impacted the global economy including Indonesia. This condition causes the movement of the rupiah to weaken following the global economy. The weakening of the rupiah causes, the economic conditions in Indonesia participate weakened. This study aims to determine the effect of money supply, gross domestic income, inflation and interest rates on the rupiah against the US dollar after the 2008 global economic crisis. The basic theory used in this research is the monetary approach theory was developed by Frenkel (1984). The analysis model used is ARCH/GARCH model with Maximum Likelihood estimation method. The empirical result of these research shows that the variable which have positive and significant influence is variable of money supply, and interest rates. Real GDP have negative and significant influence to the exchange rate. While inflation has no effect.
\end{abstract}

Keywords : exchange rate, money supply, real GDP, inflation, interest rate

\section{PENDAHULUAN}

M

enjelang akhir triwulan III-2008, perekonomian dunia dihadapkan pada satu babak baru yaitu runtuhnya stabilitas ekonomi global, seiring dengan meluasnya krisis finansial ke berbagai negara. Krisis keuangan dunia tersebut telah berimbas ke perekonomian Indonesia sebagaimana tercermin dari gejolak di pasar modal dan pasar uang. Di penghujung triwulan III-2008, intensitas krisis semakin membesar seiring dengan bangkrutnya bank investasi terbesar Amerika Serikat Lehman Brothers, yang diikuti oleh kesulitan keuangan yang semakin parah di sejumlah lembaga keuangan berskala besar di Amerika Serikat (AS), Eropa, dan Jepang. (Publikasi Bank Indonesia : 2009)

Dampak krisis finansial global menyebar dengan cepat ke seluruh wilayah negara yang sedang berkembang, termasuk ke wilayah Asia. Untuk Indonesia, akibat yang dirasakan dari krisis finansial ini adalah mata uang

$$
\text { QE Journal | Vol.07 - N } 0.02 \text { July } 2018 \text { - } 99
$$


rupiah menjadi terdepresiasi sehingga mengakibatkan terjadinya krisis ekonomi dan krisis kepercayaan terhadap mata uang domestik. Kondisi ini menyebabkan nilai tukar rupiah melemah mengikuti kecenderungan global hingga mencapai titik terendah senilai Rp. 12.151 per US\$ pada November 2008. Pasca krisis finansial global kondisi nilai tukar rupiah terhadap dollar Amerika sempat kembali menguat hingga kuartal ketiga 2011. Namun di kuartal keempat 2011 hingga tahun 2016, nilai tukar rupiah terhadap dollar terus berfluktuatif.

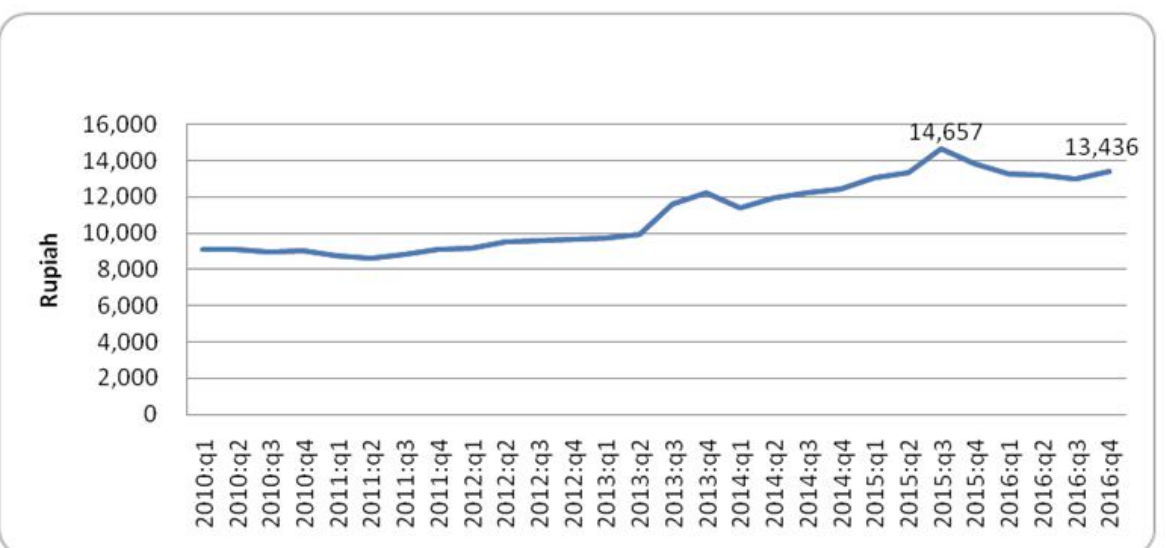

Sumber : Kurs Tengah Bank Indonesia

Gambar 1.1 Fluktuasi Nilai Tukar Rupiah Terhadap Dolar Amerika Periode Q1.2010 - Q4. 2016

Berdasarkan fenomena yang terjadi dan berbagai hal yang telah diuraikan diatas, maka peneliti membatasi permasalahan pada (1).Apakah terdapat pengaruh secara parsial dan simultan selisih jumlah uang beredar (M2), Produk Domestik Bruto riil (PDB riil), inflasi, dan tingkat suku bunga antara Indonesia dan Amerika terhadap nilai tukar rupiah atas dollar Amerika Serikat setelah krisis ekonomi global 2008 periode Q1. 2010 Q4.2016 ?; (2).Seberapa besar tingkat elastisitas nilai tukar rupiah atas dollar Amerika Serikat terhadap jumlah uang beredar (M2), Produk Domestik Bruto riil (PDB riil), inflasi, dan tingkat suku bunga Indonesia dan Amerika setelah krisis ekonomi global 2008 periode Q1.2010 - Q4. 2016

"Kurs adalah tingkat harga yang disepakati penduduk kedua negara untuk saling melakukan perdagangan. Kurs dibedakan atas dua, yaitu kurs nominal dan kurs riil. Kurs nominal adalah harga relatif dari mata uang 
dua negara. Sedangkan kurs riil adalah harga relatif dari barang-barang di antara dua negara." (Mankiw, 2007)

Model moneter memaparkan bahwa nilai tukar valuta asing diperoleh dengan mengkombinasikan teori kuantitas uang, konsep permintaan dan penawaran uang dan berlakunya hukum satu harga (teori PPP). Ringkasnya teori moneter mengusulkan bahwa kurs (nilai tukar) dipengaruhi oleh penawaran uang, pendapatan dan tingkat bunga. (Wilson, 2009)

Berdasarkan Flexible Price Monetary Model yang dikembangkan oleh (Frenkel, 1976), (Mussa, 1976), (Bilson, 1978) dalam (Frankel, Test of Monetary and Portfolio Balance Models of Exchange Rate Determination, 1984), mengasumsikan bahwa harga barang-barang sangat fleksibel dan berlaku konsep Paritas Daya Beli (Purchasing Power Parity) secara berkesinambungan (terus menerus). Model ini dibangun dengan asumsi fungsi permintaan uang yang stabil di pasar uang domestik dan internasional. Kondisi keseimbangan pasar uang domestik dan internasional, diasumsikan tergantung dari logaritma pendapatan riil, logaritma tingkat harga dan tingkat bunga nominal. Hubungan ekonomi domestik dan internasional adalah sama. Secara ringkas Flexible Price Monetary Model mengasumsikan bahwa keseimbangan kurs didorong oleh kelebihan penawaran uang relatif, tingkat bunga nominal dan ekspektasi inflasi. (Civcir, 2003). Menurut (Salvatore, 2013), nilai tukar adalah harga relatif dari uang, yang dipengaruhi oleh permintaan dan penawaran uang.. Peningkatan permintaan uang domestik sebagai akibat dari peningkatan pendapatan domestik atau penurunan ekspektasi inflasi dan ini menyebabkan mata uang domestik terapresiasi. Suatu negara yang menghadapi tekanan inflasi yang lebih besar daripada negara-negara lain (yang dihasilkan dari pertumbuhan jumlah uang beredar yang lebih cepat sehubungan dengan pertumbuhan pendapatan riil dan permintaan uang) akan mendapati kursnya meningkat (mata uang domestik terdepresiasi). Di sisi lain, suatu negara yang menghadapi tekanan inflasi yang lebih rendah daripada negara-negara lain di dunia akan mendapati kursnya menurun (mata uang domestik terapresiasi).

Dornbusch (1976) menawarkan sebuah model ekspektasi yang lebih masuk akal, yaitu harga-harga bersifat kaku dalam jangka pendek (Sticky Price Monetary Model). Konsep PPP diasumsikan hanya ada dalam jangka 
panjang. Perubahan tingkat bunga nominal refleksi dari perubahan kebijakan moneter yang ketat. Dalam jangka pendek, nilai tukar bisa menyimpang dari jalur ekuilibriumnya menuju keseimbangan jangka panjang. Gap (celah) tersebut diharapkan dapat ditutup dengan kecepatan penyesuaian (speed of adjustment). Dalam jangka panjang berlaku konsep PPP. Selisih tingkat bunga mencerminkan posisi likuiditas. Peningkatan tingkat bunga domestik mengindikasikan sebuah kekurangan relatif dari likuiditas pasar uang domestik, meningkatan aliran modal masuk dan menyebabkan apresiasi mata uang domestik.

Frankel (1979) mengembangkan Sticky Price Monetary Model milik Dornbusch (1976) yang dikenal dengan The Real Interest Differential Monetary Model. Frankel menggunakan dasar persamaan Flexible Monetary Model dalam jangka panjang yang ditandai dengan garis diatas. Asumsi yang digunakan Frankel dalam model ini adalah tingkat depresiasi yang diharapkan dari kurs yaitu fungsi dari kesenjangan (gap) antara kurs saat ini dengan tingkat keseimbangan jangka panjangnya ditambah selisih ekspektasi inflasi jangka panjang antara domestik dan internasional. Kurs dalam jangka pendek diharapkan untuk mengembalikan pada tingkat keseimbangan jangka panjangnya. Dalam jangka panjang selisih kurs, kemudian tingkat yang diharapkan dari depresiasi mata uang akan sama dengan selisih inflasi domestik dengan internasional. (Civcir, 2003).

Bentuk ekspektasi model ini lebih rasional di mana harga menyesuaikan secara bertahap dari waktu ke waktu dalam menanggapi kelebihan permintaan barang tetapi juga bergerak sesuai dengan tingkat inflasi yang mendasarinya. Jika nilai tukar yang berlaku saat transaksi dilakukan berada di bawah tingkat keseimbangan jangka panjang, maka mata uang yang diharapkan akan mengalami depresiasi. Demikian sebaliknya. (Frankel : 1984) Penyimpangan kurs saat ini terhadap tingkat keseimbangannya disebabkan oleh perbedaan tingkat bunga riil. Jika tingkat bunga riil internasional lebih tinggi dari tingkat bunga riil domestik maka akan terjadi aliran modal keluar. Hal ini akan menyebabkan mata uang domestik terdepresiasi. Sebaliknya jika tingkat bunga riil domestik lebih tinggi dari tingkat bunga riil internasional maka akan terjadi aliran modal keluar sehingga mata uang domestik akan terapresiasi. (setyowati, 2003 : 166). Penjelasan teori ini dapat dilihat pada model The Real Interest Differential Monetary Model sebagai berikut : (Frankel : 1979) 


$$
s=\left(m^{-}-m^{-\mathrm{I}} *\right)-\left(\left(y^{-}-y^{-\mathrm{I}} *\right)+(\beta+1 /(\theta))\left(\pi^{-}-\pi^{-\mathrm{I}} *\right)-1 / \theta\left[\left(i-i^{\mathrm{I}} *\right)\right.\right.
$$

dimana

s : : kurs spot valuta asing;

$\mathrm{m} \quad$ : $\log$ selisih penawaran uang;

$\left(\bar{y}-\bar{y}^{*}\right): \log$ selisih pendapatan riil;

$\left(\pi^{-}-\pi^{-\top} *\right.$ : selisih tingkat inflasi;

$\left(i-i^{*}\right)$ : selisih tingkat suku bunga riil.

Persamaan (1) merupakan model moneter yang akan digunakan dalam penelitian ini. Meningkatnya kurs (depresiasi mata uang domestik) sebagai akibat dari kelebihan penawaran uang domestik. Sebaliknya menurunnya kurs (apresiasi mata uang domestik) sebagai akibat dari kekurangan penawaran uang domestik (Salvatore, 2013). Berdasarkan persamaan (1) dalam jangka pendek koefisien penawaran uang dan tingkat inflasi yang diharapkan adalah positif. Dengan asumsi ceteris paribus (bila semua kondisi lainnya tetap). Kenaikan penawaran uang akan menyebabkan kurs meningkat (mata uang domestik terdepresiasi). Kenaikan penawaran uang akan memperbesar tingkat permintaan barang dan jasa sehingga meningkatkan ekspektasi inflasi. (Krugman, Obstfeld, \& Melitz, 2012). Sedangkan koefisien pendapatan riil adalah negatif. Kenaikan selisih pendapatan riil akan menyebabkan penurunan kurs (mata uang domestik terapresiasi). Kenaikan pendapatan mendorong permintaan akan uang domestik meningkat. Sehingga mata uang domestik akan terapresiasi. Namun koefisien tingkat bunga menunjukkan dua tanda, positif dan negatif. Hal ini terjadi karena perbedaan koefisien pada perbedaan tingkat bunga terdiri dari dua komponen berbeda yang menunjukkan berbagai cara yang digunakan perbedaan tingkat bunga dalam mempengaruhi perubahan nilai tukar. ( (Kholidin, 2002), (Setyowati, 2003), (Tampubolon, 2015)). Kenaikan suku bunga domestik menurunkan permintaan mata uang domestik dan menyebabkan depresiasi.(Frankel,1979). Ketika suku bunga riil domestik meningkat, mata uang domestik terapresiasi. (Mishkin, 2011).

Studi empiris tentang faktor-faktor yang mempengaruhi nilai tukar dengan menggunakan model moneter telah banyak dilakukan baik di dalam negeri maupun di luar negeri dan menghasilkan temuan yang relatif beragam. Untuk kasus di Indonesia, Oktavia,dkk (2013) menganalisis kurs dan 
money supply di Indonesia. Dengan menggunakan data 2000.Q1 - 2010.Q4. Model persamaan simultan dengan motode Two Stage Least Squared (TSLS). Variabel bebas $(\mathrm{X})$ meliputi jumlah uang beredar, pendapatan, suku bunga domestik, inflasi dan neraca perdagangan. Sedangkan variabel terikat $(Y)$ yaitu nilai tukar. Dari hasil penelitian diperoleh data bahwa variabel jumlah uang beredar, pendapatan dan inflasi berpengaruh positif dan signifikan terhadap nilai tukar. Variabel tingkat suku bunga domestik berpengaruh negatif dan signifikan terhadap nilai tukar. Sedangkan variabel neraca perdagangan tidak berpengaruh terhadap nilai tukar.

Tjahjawandita \& Santoso (2016), meneliti pengaruh variabel makro ekonomi dan variabel fiskal terhadap nilai tukar nominal efektif rupiah dengan menggunakan teori pendekatan moneter yang dikembangkan oleh Wilson (2009) dengan memasukkan variabel kebijakan fiskal . Variabel bebas penelitian meliputi indeks harga domestik, indeks harga impor, jumlah uang beredar, GDP, dan hutang domestik dengan periode data 1990.Q1 - 2015.Q2. Menggunakan teknik analisis Engle - Error Correction Model. Hasil penelitian menjelaskan bahwa dalam jangka pendek, pendekatan moneter versi harga kaku (sticky price) mampu menjelaskan pergerakan nilai tukar efektif Rupiah. Variabel yang berpengaruh positif terhadap nilai tukar adalah jumlah uang beredar. Variabel yang berpengaruh negatif terhadap nilai tukar adalah indeks harga impor dan hutang domestik sedangkan GDP tidak berpengaruh. Dalam jangka panjang, variabel yang berpengaruh positif terhadap nilai tukar adalah jumlah uang beredar. Variabel indeks harga impor, GDP dan hutang domestik berpengaruh negatif terhadap nilai tukar efektif Rupiah.

Studi empiris dengan menggunakan teori pendekatan moneter juga dilakukan diluar negeri. Zakaria dan Ahmad (2009) melakukan penelitian dengan membandingkan nilai tukar Pakistan Rupee dengan 17 negara mitra dagang Pakistan. Periode penelitian 1983.Q1 - 2007.Q4. Membandingkan model moneter harga fleksibel (flexible price monetary model) dengan model model moneter harga kaku (sticky price monetary model) dan model moneter perbedaan tingkat suku bunga riil (real interest rate differential monetary model). Variabel bebas yang diteliti adalah jumlah uang beredar, pendapatan, tingkat suku bunga dan inflasi. Hasil menunjukkan bahwa model moneter harga fleksibel yang paling baik menjelaskan keadaan nilai tukar di Pakistan. Variabel selisih jumlah uang 
beredar memiliki pengaruh positif dan signifikan terhadap nilai tukar Pakistan Rupee hanya pada 12 negara mitra dagang Pakistan. Variabel selisih pendapatan memiliki pengaruh negatif dan signifikan terhadap nilai tukar Pakistan Rupee hanya pada 8 negara mitra dagang Pakistan. Variabel selisih tingkat suku bunga memiliki pengaruh yang signifikan terhadap nilai tukar Pakistan Rupee hanya pada 3 negara mitra dagang Pakistan, namun ada 1 yang memiliki tanda negatif. Variabel selisih inflasi memiliki pengaruh yang signifikan terhadap nilai tukar Pakistan Rupee pada 10 negara mitra dagangnya. Hanya 5 negara memiliki tanda arah yang positif dan 5 negara lagi memiliki tanda arah yang negatif terhadap nilai tukar Pakistan Rupee.

Jimoh (2004), menganalisis nilai tukar Naira terhadap dollar Amerika dengan lokasi penelitian di Nigeria. Menggunakan metode pendekatan moneter harga fleksibel (flexible price monetary model) dan model moneter harga kaku (sticky price monetary model). Estimasi penelitian dengan menggunakan teknik Ordinary Least squares (OLS) untuk model moneter harga kaku (sticky price monetary model) dan Autoregressive order one Generalised Least Squares \{AR(1) GLS untuk model moneter harga fleksibel (flexible price monetary model). Hasil penelitian menunjukkan model harga kaku (sticky price monetary model) lebih baik untuk mengestimasi nilai tukar di Nigeria dengan teknik OLS. Jumlah uang beredar dan tingkat suku bunga berpengaruh positif dan signifikan terhadap nilai tukar naira atas dollar Amerika dan variabel pendapatan berpengaruh negatif dan signifikan terhadap nilai tukar naira atas dollar Amerika.

\section{METODE PENELITIAN}

Metode penelitian yang digunakan dalam penelitian ini adalah pendekatan kuantitatif. Menurut Kuncoro (2011 : 3), metode kuantitatif adalah pendekatan ilmiah terhadap pengambilan keputusan manajerial dan ekonomi. Metode pengumpulan data yang dilakukan dalam penelitian ini adalah metode tidak langsung (indirect method) yaitu dokumentasi melalui pencatatan atau mendownload data. Jenis data yang digunakan dalam penelitian ini adalah data sekunder dalam bentuk data runtun waktu (time series), dengan periode penelitian Q1.2010 hingga Q4.2016. Data diambil dari berbagai sumber resmi. Untuk data Indonesia diambil dari Badan Pusat Statistik dan Bank Indonesia, sedangkan data Amerika Serikat diambil melalui website resmi, yaitu : https://research.stlouisfed.org/ 
http://www.inflation.eu/inflation-rates, https://data.worldbank.org/country dan http://data.imf.org/(IFS). Model penelitian menggunakan persamaan non-linier dengan teknik analisis model GARCH dan metode estimasi menggunakan Maximum Likelihood. Model GARCH digunakan untuk menganalisis data ekonomi yang menunjukkan volatilitas yang tinggi.

Adapun model penelitian ini, yaitu :

$$
\ln \int_{\mathbb{E}_{\mathrm{t}}}=\beta_{0}+\beta_{1} \ln _{\mathrm{MZ}_{\mathrm{t}}}+\boldsymbol{\beta}_{2} \ln _{\mathrm{PDE}_{\mathrm{t}}}+\boldsymbol{\beta}_{3} \ln _{\mathrm{P}_{\mathrm{t}}}+\boldsymbol{\beta}_{4} \ln _{\mathrm{i}_{\mathrm{t}}}+\mathrm{e}_{\mathrm{t}}
$$

Untuk membentuk model GARCH $(1,1)$, maka varian residual (et) persamaan (3.1) diubah kedalam bentuk

$$
\begin{gathered}
\sigma_{t}^{2}=\operatorname{var}\left(e_{t}\right) \\
\sigma_{\downarrow} t^{\tau_{2}}={ }_{1} 0+{ }_{1} 1 e_{\downarrow}(t-1)^{\tau_{2}}+\lambda_{1} 1 \sigma_{1}(t-1)^{\hat{f}_{2}}
\end{gathered}
$$

Dimana :

E : Nilai tukar rupiah terhadap dollar Amerika

M2 : Selisih jumlah uang beredar riil Indonesia dan Amerika

PDB : Selisih PDB riil di Indonesia dan Amerika.

$\mathrm{P} \quad$ : Selisih inflasi Indonesia dan Amerika

i : Selisih suku bunga riil Indonesia dan Amerika

$\mathbf{e}_{\mathbf{t}}$ : variabel gangguan (error term)

ln : logaritma natural

Model GARCH ini menjelaskan bahwa varian residual tidak hanya dipengaruhi oleh residual periode lalu (e-t) tetapi juga varian residual periode yang lalu $\left(\sigma_{\mathrm{t}}\right)$. Setelah dilakukan penentuan model GARCH, maka dilakukan uji asumsi dan uji hipotesis atas model yang telah diestimasikan tersebut. Uji asumsi meliputi uji normalitas, uji auokorelasi dan uji heteroskedastisitas. Uji hipotesis terdiri dari uji $\mathrm{t}$ dan uji F.inier berganda didapat hasil bahwa persamaan linier mengandung heteroskedastisitas. Uji hipotesis terdiri dari uji t dan uji F.

\section{HASIL DAN PEMBAHASAN}

\section{Hasil Uji ARCH}

Dari hasil uji ARCH persamaan regresi linier berganda didapat hasil bahwa persamaan linier mengandung heteroskedastisitas. Hasil ini dapat dilihat pada tabel 4.2 berikut : 
Tabel 4.2 Hasil Uji ARCH test

\begin{tabular}{llll}
\multicolumn{4}{l}{ Heteroskedasticity Test: ARCH } \\
\hline \hline F-statistic & 8.442694 & Prob. F(1,25) & 0.0076 \\
ObsR-squared & 6.816220 & Prob. Chi-Square(1) & 0.0090 \\
\hline \hline
\end{tabular}

Hasil Uji ARCH menunjukkan bahwa residual error mengandung heteroskedastisitas yang dapat dilihat dari nilai Prob. Chi Squares sebesar $0.0090<\alpha=0.05$.

\section{Hasil Estimasi Model GARCH $(1,1)$}

Model terbaik yang didapatkan dari model ARCH/GARCH ini adalah model GARCH $(1,1)$ dengan memasukkan variabel bebas inflasi (ln_P) kedalam model varian errornya. Hasil empiris ini dapat dilihat pada tabel 4.3 berikut :

Tabel 4.3 Hasil Uji Model GARCH $(1,1)$

\begin{tabular}{|c|c|c|c|c|}
\hline $\begin{array}{l}\text { Dependent Variable: } \\
\text { Method: ML - ARCH } \\
\text { Date: } 04 / 25 / 18 \text { Tim } \\
\text { Sample: } 2010 Q 120 \\
\text { Included observation } \\
\text { Convergence achiev } \\
\text { Presample variance: } \\
\text { GARCH }=\mathrm{C}(6)+\mathrm{C}(7\end{array}$ & $\begin{array}{l}\text { E } \\
\text { uardt) - Norn } \\
25 \\
\text { ter } 39 \text { iteratio } \\
\text { kcast (param } \\
\text { SID }(-1)^{\wedge} 2+C\end{array}$ & hal distribution & $+C(9)^{*} L N_{2}$ & \\
\hline Variable & Coefficient & Std. Error & z-Statistic & Prob. \\
\hline C & 2.812159 & 0.005639 & 498.6865 & 0.0000 \\
\hline LN_M2 & 1.494254 & 0.012179 & 122.6906 & 0.0000 \\
\hline LN_PDB & -0.461606 & 0.014520 & -31.79157 & 0.0000 \\
\hline LN_P & 0.008225 & 0.010745 & 0.765424 & 0.4440 \\
\hline LN_I & 0.090569 & 0.008778 & 10.31820 & 0.0000 \\
\hline \multicolumn{5}{|c|}{ Variance Equation } \\
\hline $\mathrm{C}$ & 1.47E-05 & 0.000273 & 0.054099 & 0.9569 \\
\hline $\operatorname{RESID}(-1)^{\wedge} 2$ & -0.257735 & 0.046131 & -5.586968 & 0.0000 \\
\hline GARCH(-1) & 1.130428 & 0.116789 & 9.679215 & 0.0000 \\
\hline LN_P & 0.000131 & 0.000172 & 0.764349 & 0.4447 \\
\hline R-squared & 0.931007 & \multicolumn{2}{|c|}{ Mean dependent var } & 9.291860 \\
\hline Adjusted R-squared & 0.901958 & \multicolumn{2}{|c|}{ S.D. dependent var } & 0.177750 \\
\hline S.E. of regression & 0.055656 & \multicolumn{2}{|c|}{ Akaike info criterion } & -3.263735 \\
\hline Sum squared resid & 0.058855 & \multicolumn{2}{|c|}{ Schwarz criterion } & -2.835526 \\
\hline Log likelihood & 54.69229 & \multicolumn{2}{|c|}{ Hannan-Quinn criter. } & -3.132827 \\
\hline F-statistic & 32.04902 & \multicolumn{2}{|c|}{ Durbin-Watson stat } & 0.975415 \\
\hline Prob(F-statistic) & 0.000000 & & & \\
\hline
\end{tabular}


Hasil empiris ini menghasilkan model penelitian sebagai berikut :

$$
\begin{gathered}
\text { LN_E }=2.8126+1.4943 \mathrm{LN} \_M 2^{*}-0.4616 \mathrm{LN} \_P D B^{*}+ \\
\text { 0.0082LN_P }+0.0906 \text { LN_I* } \\
\boldsymbol{\sigma}_{t}^{2}=0.0000147-0.257735 \boldsymbol{e}_{t-1}^{2}{ }^{*}+1.130428 \boldsymbol{\sigma}_{t-1}^{2}{ }^{*}+ \\
\text { 0.0001312LN_P }
\end{gathered}
$$

“*” adalah tanda signifikan pada tingkat $\alpha<0,005$. Model analisis ini adalah model terbaik dibandingkan model-model sebelumnya walaupun variabel inflasi tidak signifikan namun variabel ARCH/GARCH signifikan.

\section{Uji Heteroskedastisitas}

Tabel 4.4 Hasil Uji White

\begin{tabular}{llll}
\multicolumn{4}{l}{ Heteroskedasticity Test White } \\
\hline \hline F-statistc & 0.597440 & Prob. F(13,14) & 0.8196 \\
Obs*R-squared & 9.990857 & Prob. Chi-Square(13) & 0.6947 \\
Scaled explained SS & 815807.0 & Prob. Chi-Square(13) & 0.0000 \\
\hline \hline
\end{tabular}

Probability dari Obs*R-squared menunjukkan angka lebih besar dari 5\% atau 0,05.Dengan demikian diputuskan untuk menerima hipotesis yaitu

\begin{tabular}{|c|c|c|c|c|c|c|c|c|}
\hline \multicolumn{9}{|c|}{$\begin{array}{l}\text { Date: 04/24/18 Time: } 23: 48 \\
\text { Sample: } 2010 \mathrm{Q} 1 \text { 2016Q4 } \\
\text { Included observations: } 28\end{array}$} \\
\hline Autocorr & relation & Partial Cor & relation & & $A C$ & PAC & Q-Stat & Prob \\
\hline 1 & ا & 15 & & 1 & 0.285 & 0.285 & 2.5349 & 0.111 \\
\hline 15 & $\sqsupset$ । & 10 & 1 & 2 & 0.199 & 0.128 & 3.8170 & 0.148 \\
\hline 10 & 1 & 1 & 1 & 3 & 0.098 & 0.013 & 4.1412 & 0.247 \\
\hline 10 & 1 & 1 & 1 & 4 & 0.063 & 0.011 & 4.2788 & 0.370 \\
\hline 1 & 1 & 10 & 1 & 5 & -0.012 & -0.050 & 4.2840 & 0.509 \\
\hline 1 & 1 & 1 & 1 & 6 & -0.005 & -0.002 & 4.2848 & 0.638 \\
\hline 1 & 1 & 1 & 1 & 7 & 0.029 & 0.043 & 4.3183 & 0.742 \\
\hline 15 & 1 & 10 & 1 & 8 & 0.102 & 0.100 & 4.7564 & 0.783 \\
\hline $1-$ & 1 & $1 \square$ & 1 & 9 & -0.166 & -0.248 & 5.9748 & 0.742 \\
\hline 15 & 1 & 1 & 1 & 10 & -0.093 & -0.033 & 6.3763 & 0.783 \\
\hline 1 드. & 1 & 1 C & 1 & 11 & -0.169 & -0.105 & 7.7951 & 0.732 \\
\hline 1 미 & 1 & 10 & 1 & 12 & -0.161 & -0.070 & 9.1538 & 0.690 \\
\hline
\end{tabular}
residual model diatas tidak mengandung heteroskedastisitas.

\section{Uji Autokorelasi}

Tabel 4.5 Hasil Uji Correlogram 
Dari tabel 4.5 dapat dilihat bahwa probability sudah lebih besar dari $\alpha=0,05$ (tidak ada lagi yang signifikan. Dapat disimpulkan residual model tidak mengandung autokorelasi.

\section{Uji Normalitas}

Hasil empiris uji normalitas menunjukkan probability Jarque-Bera 0,466892 lebih besar dari 0,05. Sehingga dapat disimpulkan bahwa residual berdistribusi normal.

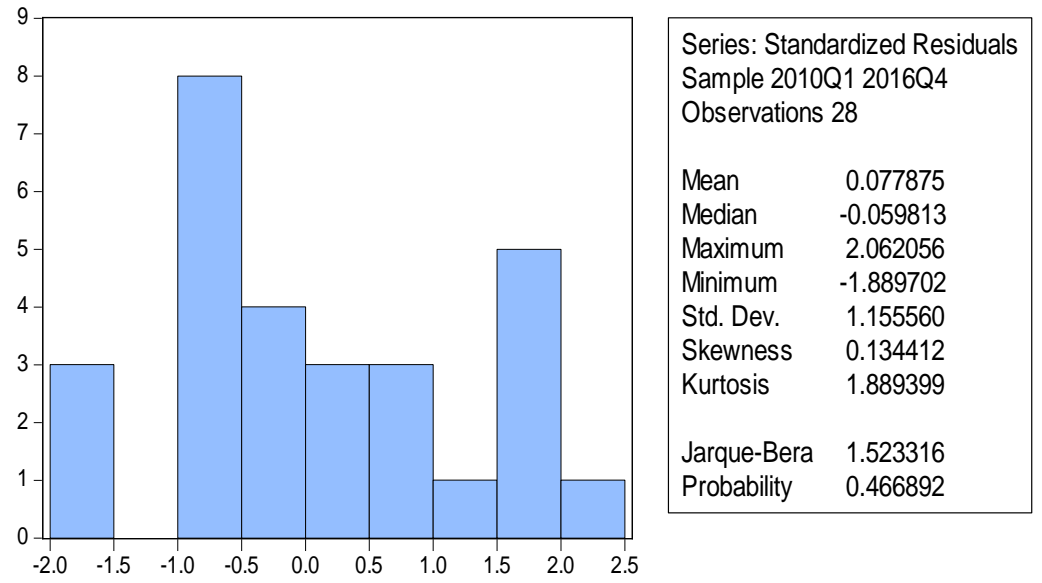

Gambar 4.1 Hasil Uji Histogram Jarque Bera

\section{Koefisien Determinasi $\left(\mathbf{R}^{2}\right)$}

Hasil empiris menunjukkan bahwa model memiliki koefisien determinasi sebesar 0,901958. Hasil ini dapat menjelaskan bahwa variasi jumlah uang beredar, PDB, inflasi dan tingkat suku bunga dapat menjelaskan nilai tukar rupiah atas dollar Amerika setelah krisis ekonomi global 2008 sebesar $90.19 \%$ sedangkan sisanya $9,81 \%$ dijelaskan oleh variabel lain yang tidak diteliti dalam penelitian ini.

\section{Hasil Uji $t$}

Hasil empiris menunjukkan bahwa secara parsial jumlah uang beredar dan tingkat bunga berpengaruh positif dan signifikan terhadap nilai tukar rupiah atas dollar Amerika setelah krisis ekonomi global 2008. PDB riil berpengaruh negative dan signifikan terhadap nilai tukar rupiah atas dollar Amerika setelah krisis ekonomi global 2008. Sedangkan inflasi tidak berpengaruh. 


\section{Hasil Uji F}

Secara simultan hasil empiris menunjukkan bahwa jumlah uang beredar, PDB riil, inflasi dan tingkat bunga berpengaruh signifikan terhadap nilai tukar rupiah atas dollar Amerika setelah krisis ekonomi global 2008.

Kenaikan selisih jumlah uang beredar (M2) sebesar 1\% akan menyebabkan kenaikan nilai tukar rupiah atas dollar Amerika setelah krisis keuangan global 2008 sebesar 1.49\%. Hasil empiris ini sesuai dengan harapan teori dan hipotesis yang diajukan. Peningkatan jumlah uang beredar dalam arti luas (M2) menyebabkan mata uang rupiah terdepresiasi. Peningkatan penawaran uang memperbesar permintaan barang dan jasa. Akibat dari kelebihan permintaan barang dan jasa ini, menyebabkan negara harus mengimpor. Sehingga permintaan mata uang asing akan meningkat dan menyebabkan mata uang domestik terdepresiasi.

Kenaikan selisih pendapatan domestik bruto riil (PDB riil) sebesar 1\% akan menyebabkan penurunan nilai tukar rupiah atas dollar Amerika setelah krisis ekonomi global 2008 sebesar $0.46 \%$. Hasil empiris ini sesuai dengan harapan teori dan hipotesis yang diajukan. Kenaikan pendapatan menyebabkan meningkatnya permintaan mata uang domestik sehingga mata uang domestik akan terapresiasi.

Kenaikan selisih inflasi $(\mathrm{P})$ sebesar $1 \%$ akan menyebabkan kenaikan nilai tukar rupiah atas dollar Amerika setelah krisis ekonomi global 2008 sebesar $0.0082 \%$. Hasil empiris ini sesuai dengan harapan teori dan hipotesis yang diajukan. Kenaikan penawaran uang akan memperbesar tingkat permintaan barang dan jasa sehingga meningkatkan inflasi. Tingginya tingkat inflasi menyebabkan harga barang domestik relatif lebih mahal dari harga barang impor. Harga yang lebih mahal menyebabkan turunnya daya saing barang domestik di pasar internasional. Masyarakat terdorong untuk membeli barang impor yang relatif lebih murah dari barang domestik. Naiknya impor menyebabkan permintaan akan mata uang asing meningkat sehingga mata uang domestik terdepresiasi.

Kenaikan selisih tingkat suku bunga (i) sebesar 1\% akan menyebabkan kenaikan nilai tukar rupiah atas dollar Amerika setelah krisis ekonomi global 2008 sebesar $0.091 \%$. Hasil empiris ini sesuai dengan harapan teori dan hipotesis yang diajukan. Ketika suku bunga domestik naik karena perkiraan kenaikan pada inflasi, maka mata uang domestik terdepresiasi. 
Selisih tingkat bunga dipandang sebagai perwakilan dari tingkat ekspektasi inflasi relatif, baik karena arus investasi internasional sama dengan suku bunga riil atau karena paritas suku bunga menjamin bahwa selisih tingkat bunga sama dengan depresiasi yang diharapkan, dan paritas daya beli menjamin bahwa depresiasi sama dengan inflasi relatif.

\section{Hasil Pengecekan Elastisitas}

Dari keseluruhan variabel bebas yang diteliti dapat dikatakan bahwa elastisitas nilai tukar rupiah atas dollar Amerika setelah krisis ekonomi global 2008 terhadap jumlah uang beredar (M2) adalah yang paling elastis. Karena ukuran elastisitas yang elastis adalah variabel yang memiliki nilai koefisien > $>$. Hasil elastisitas ini menunjukkan bahwa intervensi pemerintah dalam mempengaruhi nilai tukar rupiah atas dollar Amerika setelah krisis ekonomi global 2008 melalui kebijakan moneter memegang peranan yang sangat penting.

\section{SIMPULAN DAN SARAN}

Dari hasil estimasi yang diperoleh, secara parsial variabel jumlah uang beredar (M2) dan tingkat suku bunga berpengaruh positif dan signifikan terhadap nilai tukar rupiah terhadap dolar Amerika pasca krisis ekonomi global 2008 periode Q1. 2010 - Q4.2016, sedangkan variabel PDB riil berpengaruh negatif dan signifikan terhadap nilai tukar rupiah atas dollar Amerika. Namun variabel makro inflasi tidak berpengaruh. Secara simultan variabel jumlah uang beredar (M2), Produk Domestik Bruto riil (PDB riil), inflasi, dan tingkat suku bunga berpengaruh signifikan terhadap nilai tukar rupiah atas dollar Amerika Serikat setelah krisis ekonomi global 2008 periode Q1. 2010 - Q4.2016.

\section{DAFTAR PUSTAKA}

Bilson, J. (1978). The Monetary Approach to the Exchange Rate-Some Emprical Evidence. IMF Staff Papers 25 (March), 48-75.

Civcir, I. (2003). The Monetary Model of the Exchange Rate under High Inflation. Czech Journal of Economics and Finance, 53, 113-128.

Dornbusch, R. (1976). Expectations and Exchange Rate Dynamics. The Journal of Political Economy 84(6), 1161-1176. 
Frankel, J. A. (1979). On the Mark A Theory of Floating Exchange Rates Based on Real Interest Differentials. The American Economic Review 69(4), 610-622.

Frankel, J. A. (1984). Test of Monetary and Portfolio Balance Models of Exchange Rate Determination. (J. F. Bilson, R. C. Marston, \& eds, Eds.) The National Bureau of Economic Research, 239-260.

Frenkel, J. (1976). A Monetary Approach to the Exchange Rate : Doctrinal aspects and empirical evidence. Scandinavian Journal of Economics 76 (May), 200-224.

Gujarati, D. N. (2012). Dasar-dasar Ekonometrika. Jakarta: Erlangga.

Iskandarsyah, N. (2013). Faktor-Faktor Yang Mempengaruhi Pergerakan Rupiah : Analisis Model Moneter Dengan Menggunakan Johansen Cointegration dan Error Correction Model. Widyariset 16(1), 39-48.

Jimoh, A. (2004). The Monetary Approach to Exchange Rate Determination : Evidence From Nigeria. Journal of Economic Coorporation, Statistical Economic and Social Research and Training Centre for Islamic Countries (SESRIC).

Kholidin, A. (2002). Analisis Faktor-Faktor Yang Mempengaruhi Perubahan Nilai Tukar Rupiah Terhadap Dollar Amerika. Tesis. Semarang, Jawa Tengah: Universitas Diponegoro.

Krugman, P. R., Obstfeld, M., \& Melitz, M. J. (2012). International Economics. United States of America: Pearson.

Kuncoro, M. (2011). Metode Kuantitatif. Yogyakarta: UPP STIM YKPN.

Mankiw, N. G. (2007). Makroekonomi. Jakarta: Erlangga.

Mishkin, F. S. (2011). Ekonomi Uang, Perbankan dan Pasar Keuangan. Jakarta: Salemba Empat.

Mussa, M. (1976). The Exchange Rate, The Balance of Payments, and Monetary and Fiscal Policy Under A Regime of Controlled Floating. Scandinavian Journal of Economics 78 (May), 229-48.

Oktavia, A. L., Sentosa, S. U., \& Aimon, H. (2013). Analisis Kurs dan Money Supply di Indonesia. Jurnal Kajian Ekonomi I(02), 149-165. 
Salvatore, D. (2013). International Economics. United States of America: John Wiley \& Sons, Inc.

Setyowati, E. (2003). Faktor-Faktor Yang Mempengaruhi Nilai Tukar Rupiah Terhadap Dolar Amerika Dengan Model Koreksi Kesalahan Engle_Granger (Pendekatan Moneter). Jurnal Ekonomi Pembangunan, 162-186.

Shinta R.I Soekro, e. a. (2008). Bangkitnya Perekonomian Asia Timur : Satu Dekade Setelah Krisis. Jakarta: PT Elex Media Komputindo.

Simorangkir, I., \& Suseno. (2005, April 27). Sistem dan Kebijakan Nilai Tukar. Seri Kebanksentralan No. 12, pp. 1-46.

Tampubolon, A. (2015). Analisis Determinan Perubahan Nilai Tukar Rupiah Terhadap Dollar Amerika Periode Setelah Krisis Ekonomi Global 2008. Tesis. Medan, Sumatera Utara, Indonesia: Pasca Sarjana Universitas Negeri Medan.

Tjahjawandita, A., \& Santoso, T. (2016). Monetary Approach of Rupiah's Exchange Rate. Article of Unpad Repository.

Bilson, J. (1978). The Monetary Approach to the Exchange Rate-Some Emprical Evidence. IMF Staff Papers 25 (March), 48-75.

Civcir, I. (2003). The Monetary Model of the Exchange Rate under High Inflation. Czech Journal of Economics and Finance, 53, 113-128.

Dornbusch, R. (1976). Expectations and Exchange Rate Dynamics. The Journal of Political Economy 84(6), 1161-1176.

Frankel, J. A. (1979). On the Mark A Theory of Floating Exchange Rates Based on Real Interest Differentials. The American Economic Review 69(4), 610-622.

Frankel, J. A. (1984). Test of Monetary and Portfolio Balance Models of Exchange Rate Determination. (J. F. Bilson, R. C. Marston, \& eds, Eds.) The National Bureau of Economic Research, 239-260.

Frenkel, J. (1976). A Monetary Approach to the Exchange Rate : Doctrinal aspects and empirical evidence. Scandinavian Journal of Economics 76 (May), 200-224.

Gujarati, D. N. (2012). Dasar-dasar Ekonometrika. Jakarta: Erlangga. 
Iskandarsyah, N. (2013). Faktor-Faktor Yang Mempengaruhi Pergerakan Rupiah : Analisis Model Moneter Dengan Menggunakan Johansen Cointegration dan Error Correction Model. Widyariset 16(1), 39-48.

Jimoh, A. (2004). The Monetary Approach to Exchange Rate Determination : Evidence From Nigeria. Journal of Economic Coorporation, Statistical Economic and Social Research and Training Centre for Islamic Countries (SESRIC).

Kholidin, A. (2002). Analisis Faktor-Faktor Yang Mempengaruhi Perubahan Nilai Tukar Rupiah Terhadap Dollar Amerika. Tesis. Semarang, Jawa Tengah: Universitas Diponegoro.

Krugman, P. R., Obstfeld, M., \& Melitz, M. J. (2012). International Economics. United States of America: Pearson.

Kuncoro, M. (2011). Metode Kuantitatif. Yogyakarta: UPP STIM YKPN.

Mankiw, N. G. (2007). Makroekonomi. Jakarta: Erlangga.

Mishkin, F. S. (2011). Ekonomi Uang, Perbankan dan Pasar Keuangan. Jakarta: Salemba Empat.

Mussa, M. (1976). The Exchange Rate, The Balance of Payments, and Monetary and Fiscal Policy Under A Regime of Controlled Floating. Scandinavian Journal of Economics 78 (May), 229-48.

Oktavia, A. L., Sentosa, S. U., \& Aimon, H. (2013). Analisis Kurs dan Money Supply di Indonesia. Jurnal Kajian Ekonomi I(02), 149-165.

Salvatore, D. (2013). International Economics. United States of America: John Wiley \& Sons, Inc.

Setyowati, E. (2003). Faktor-Faktor Yang Mempengaruhi Nilai Tukar Rupiah Terhadap Dolar Amerika Dengan Model Koreksi Kesalahan Engle_Granger (Pendekatan Moneter). Jurnal Ekonomi Pembangunan, 162-186.

Shinta R.I Soekro, e. a. (2008). Bangkitnya Perekonomian Asia Timur : Satu Dekade Setelah Krisis. Jakarta: PT Elex Media Komputindo.

Simorangkir, I., \& Suseno. (2005, April 27). Sistem dan Kebijakan Nilai Tukar. Seri Kebanksentralan No. 12, pp. 1-46. 
Tampubolon, A. (2015). Analisis Determinan Perubahan Nilai Tukar Rupiah Terhadap Dollar Amerika Periode Setelah Krisis Ekonomi Global 2008. Tesis. Medan, Sumatera Utara, Indonesia: Pasca Sarjana Universitas Negeri Medan.

Tjahjawandita, A., \& Santoso, T. (2016). Monetary Approach of Rupiah's Exchange Rate. Article of Unpad Repository.

Widarjono, A. (2013). Ekonometrika: Pengantar dan Aplikasinya. Yogyakarta: UPP STIM YKPN.

Wilson, I. (2009). The Monetary Approach to Exchange Rates: A Brief Review and Empirical Investigation of Debt, Deficit, and Debt Management: Evidence from the United States. The Journal of Business Inquiry 8(1), 83-99.

Zakaria, M., \& Ahmad, E. (2009). Testing the Monetary Models of Exchange Rate Determination : Some New Evidence from Modern Float. Chulangkorn Journal of Economics 21(3), 125-145.

\section{Website :}

https:/www.bi.go.id

https:/www.bps.go.id

https://research.stlouisfed.org/

http:/www.inflation.eu/inflation-rates

https://data.worldbank.org/country

http://data.imf.org/

http://gamadyastatistics.blogspot.co.id/2009/04/stasioneritas.html

http://statistikceria.blogspot.co.id/2014/02/error-correction-mechanismecm.html 